\title{
MILITARY PERSONNEL AND THE FIRST AMENDMENT: "DISCREDITABLE CONDUCT" AS A STANDARD FOR RESTRICTING POLITICAL ACTIVITY*
}

Article 134 of the Uniform Code of Military Justice ${ }^{1}$ is a catch-all provision, authorizing punishment of conduct deemed a military offense, but not covered by one of the more specific articles of the Code. ${ }^{2}$ Under article 134, courts-martial may punish (1) conduct prejudicial to good order and discipline $; 3(2)$ conduct of a nature to bring discredit on the armed forces $;^{4}$ and

*United States v. Blevens, 5 U.S.C.M.A. 480, 18 C.M.R. 104 (1955).

1. 64 STAT. $142(1950), 50$ U.S.C. $\$ 728$ (1952). This provision, originally derived from the British military law, has been part of the United States system of military justice since the first American Articles of War of 1775. Winthrop, Military Law and PreceDENTS 720, 957 (2d ed., 1920 reprint).

2. Winthrop, op. cit. supra note 1 , at 720 ; see also Military Justice Procedure TM 27-255, at 2 (1945).

Conduct lacking essential elements of civil crimes can be punished under the first or second clause of art. 134. United States v. Long, 2 U.S.C.M.A. 60, 65, 6 C.M.R. 60, 65 (1952) ; United States v. Herndon, 1 U.S.C.M.A. 461, 4 C.M.R. 53 (1952). Art. 134, however, cannot be used to eliminate essential elements of crimes specifically treated by the other punitive articles. See, e.g., United States v. Hallet, 4 U.S.C.M.A. 378, 15 C.M.R. 378 (1954) (conduct which would be misbehavior before the enemy under art. 99 if cowardice were established, cannot be "failure to perform duty in the presence of the enemy" under art. 134) ; United States v. Norris, 2 U.S.C.M.A. 236, 8 C.M.R. 36 (1953) (conduct which would be "larceny" under art. 121 if intent were established, can not be "wrongful taking" under art. 134).

3. Any act of a serviceman can conceivably affect military discipline. But only conduct which is directly prejudicial to military order or discipline may be punished under this clause. Manual for Courts-Martial, United States, 1951, at If 213a (1951) (hereinafter cited as Manval). See United States v. Snyder, 1 U.S.C.M.A. 423, 425-26, 4 C.M.R. 15, 17-18 (1952).

Conduct which is too remotely related to military order and discipline to be punished under this clause may nevertheless be punishable under art. 134 as conduct of a nature to discredit the armed forces or as a crime not capital. Manual If $213 b$. See also notes 4 and 5 infra.

4. "Discredit" has been further defined as meaning "to injure the reputation of." Manual $\llbracket 213 b$.

The discreditable conduct clause applies to any offense not punishable under other articles of the Code or under other clauses of art. 134. LEGAL AND LEGrSLATIVE BASIS, Manual for Courts-Martial, United States, 1951, at 294-95 (1951); Manual $\llbracket 213 b$. Though any misconduct may discredit the armed forces, the discreditable conduct clause has been restricted to conduct having a direct effect on the reputation of the armed forces. See United States v. Snyder, 1 U.S.C.M.A. 423, 425, 4 C.M.R. 15, 17 (1952) ; LEGAL AND Legislative Basis, Manual for Courts-Martial, United States, 1951, at 295 (1951). Cf. United States v. Creath, 66 B.R. 211 (1947); Aycock \& Wurfer, Military Law Under the Uniforas CODE of Military Justice 71 (1955).

This clause was first added to the General Article in 1916, 39 STAr. 666 (1916), for the "single purpose" of subjecting retired enlisted men to punishment by court-martial for the same conduct for which retired officers were already punishable. Testimony of the Judge 
(3) crimes not capital. ${ }^{5}$ On its face, the article may reach activity which, in a civilian context, would invoke First Amendment safeguards. And in United States v. Blevens, ${ }^{6}$ the discreditable conduct clause of article 134 was used as a means of punishing affiliation of a political nature. Although a First Amendment problem was clearly present, the court failed to discuss the two vital problems in the case: whether the First Amendment applies to military personnel, and, if so, whether the discreditable conduct clause of article 134 can constitutionally be used to punish political activity.

In Blevens, an army private was convicted under the discreditable conduct clause for "affiliating. . . . with a group advocating the violent overthrow of the United States Government" with knowledge of the group's purpose.7 Blevens was stationed in the West Zone of Berlin. Faced with the possibility of court-martial for another offense, he twice fled to East Germany, remaining there for a total of six months. ${ }^{8}$ While in East Germany, Blevens was given living accommodations and funds by agents of the East German State Security Service (SSD). ${ }^{9} \mathrm{He}$ attended a Communist school and was placed in a clerical job by the SSD. Requested by SSD agents to give a written opinion on Communism, Blevens submitted an article which he copied directly

Advocate General of the Army, Hearings Before the Military Affairs Committec on Revision of the Articles of War, 1912-1920, at 83, reprinted in LEgAL AND LEGISLATIVE Basis, Manual for Courts-Martial, United States, 1951, at 295 (1951). Within a few years the "single purpose" became merely the "principal object," A MaNual Fon Courts-Martial, U.S. ArMy 283 (1917), and then only "another principal object," A Manual for Courts-Martial, U.S. Army 462 (1920). Though this clause may still be employed for its original purpose, the present Manual does not even mention this use. See Manual $\Uparrow 213 b$.

5. Only federal crimes and offenses are punishable under this clause. Manvat โ $213 c$. Violations of local state or foreign law may be punishable under the first or second clause of art. 134. Ibid. See United States v. Freeman, 15 C.M.R. 639, 642-44 (1954) (state law); United States v. Wolverton, 10 C.M.R. 641 (1953) (foreign law); United States v. Thompson, 3 U.S.C.M.A. 620, 622-23, 14 C.M.R. 38, 40-41 (1954) (dictum) (state law).

Most capital crime's are punishable under specific punitive articles of the Code. See, generally, arts. 77-132.

6. 5 U.S.C.M.A. 480, 18 C.M.R. 104 (1955).

7. The specification of the charge against Blevens read as follows :

"In that Private-2 Robert D. Blevens [did] . . . wrongfully, unlawfully and knowingly affiliate himself with a group, to wit: State Security Service of the East Zone of Germany, advocating the violent overthrow of the United States Government, he, the said Robert D. Blevens, then knowing the purpose thereof."

Id. at 483,18 C.M.R. at 107.

8. Blevens stayed in East Germany for two and one-half months on his first flight there. He was taken into military custody upon his return to the West Zone of Berlin and confined in the stockade pending investigation. Within two weeks, Blevens escaped from the stockade with the aid of Russian agents and again fled to East Germany where he remained for three and one-half months. On his second return to the West Zone, he was apprehended by French police and turned over to American military authorities. Id. at 487-89, 18 C.M.R. at 111-13.

9. The SSD, an agency of the East German Government, controls internal security and is also concerned with espionage and propaganda. Id. at 486, 18 C.M.R. at 116. 
from a Communist treatise. ${ }^{10}$ Upon returning to West Berlin, he was found guilty by a general court-martial of two acts of desertion and of escape from confinement, in addition to his conviction on the charge of discrediting the armed forces. ${ }^{11}$

In affirming Blevens' conviction, the United States Court of Military Appeals failed to recognize that the way in which the article 134 charge was stated presented constitutional issues of freedom of expression. ${ }^{12}$ The government had originally sought to establish that Blevens, by violating the Smith Act, ${ }^{13}$ had committed a "crime not capital" punishable under the third clause of article $134 .^{14}$ But the charge, though couched in the language of a Smith Act indictment, omitted an essential element of a Smith Act offense, since it failed to allege a specific intent on the part of the accused to overthrow the government by force and violence. ${ }^{15}$ Despite this omission the Court of Mili-

10. Blevens also authorized an agent of the SSD to edit any future articles that he might write. Id. at $4 \& 8,18$ C.M.R. at 112 .

11. Blevens was sentenced to thirteen years' confinement at hard labor. The maximum prison sentence authorized for each of the charges is: two years for desertion terminated voluntarily; three years for desertion terminated by apprehension; one year for escape from confinement. MaNual $\llbracket 127 c$, at 220,221 . The court held the maximum permissible prison sentence for the discreditable conduct conviction was ten years. 5 U.S.C.M.A. at 491-92, 18 C.M.R. at 115-16. Thus at least seven years of Blevens' sentence must have been based on the discreditable conduct conviction.

12. In past cases, the Court of Military Appeals has not been reluctant to discuss constitutional issues at length. See, e.g., United States v. Sutton, 3 U.S.C.M.A. 220, 227, 11 C.M.R. 220, 227 (1953). See also United States v. Voorhees, 4 U.S.C.M.A. 509, 16 C.M.R. 83 (1954); United States v. Thompson, 3 U.S.C.M.A. 620, 622-23, 14 C.M.R. 38, 40-41. (1954).

13. The Smith Act prohibits affiliation with any group advocating the violent overthrow of the government. 18 U.S.C. $\$ 2385$, para. 3 (1952).

14. Compare the specification set out at note 7 supra, with the indictment in United States v. Lightfoot, 22S F.2d 861, 863 (7th Cir. 1956) (membership clause of the Smith Act) :

"That ... the defendant has been a member of the Communist Party ... . wellknowing ... that said Communist Party 'was and is ... a group ... of persons who ... advocate the overthrow and destruction of the Government of the United States by force and violence...."

and with the charge in Scales v. United States; 227 F.2d 581, 592 (4th Cir. 1955) ("defendant became or remained a member of an organization advocating the forcible overthrow of the government. . . "). See also 18 U.S.C. \& 2385 (1952).

In addition, the law officer advised the court that the charge brought under art. 134 "pertains to that portion of [the Smith Act] which denounces the affiliation of the accused ...." Reprinted in Final Brief on behalf of Accused, pp. 14-15, United States v. Blevens, 5 U.S.C.M.A. 480, 18 C.M.R. 104 (1955). See also United States v. Blevens, 5 U.S.C.M.A. 480, 483, 18 C.M.R. 104, 107 (1955). The ten years maximum punishment authorized by the Smith Act was used as a frame of reference in determining the sentence for Blevens' discreditable conduct conviction. Id. at 491-92, 18 C.M.R. at 115-16.

15. Such specific intent must be shown in order to establish a violation of $\S 2$ (a) (3) of the Smith Act, 18 U.S.C. $\$ 2385$, para. 3 (1952). Dennis v. United States, 341 U.S. 494, 499-500 (1951) ; cf. Hartzel v. United States, 322 U.S. 680, 686-89 (1944). 
tary Appeals held that a violation of article 134 had still been alleged, since the charge included all essential elements of a discreditable conduct offense. ${ }^{10}$ Yet affiliation with a group advocating violent overthrow remained the gravamen of the conviction. The government did not allege that Blevens' activities, in themselves, tended to injure the reputation of the armed forces; his experiences in East Germany served only to establish affiliation with a Communist group. Such affiliation constitutes an exercise of political activity falling within the scope of the First Amendment protection of freedom of speech and assembly.17

With a constitutional issue before it, the court should have determined the applicability of the First Amendment to service personnel. Although military requirements may necessitate some limitations on freedom of expression, members of the armed forces are not totally denied the guarantees of the First Amendment. Certain constitutional rights are clearly inapplicable to servicemen. For example, the Fifth Amendment specifically exempts military per-

16. United States v. Blevens, 5 U.S.C.M.A. 480, 483, 18 C.M.R. 104, 107 (1955).

The absence of essential elements of civilian crimes does not preclude the applicability of the first and second clauses of art. 134. See note 2 supra.

17. The term "speech" is used in a broad sense in the First Amendment and includes a wide variety of forms of expression. See, e.g., Joseph Burstyn, Inc. v. Wilson, 343 U.S. 495, 501-02 (1952) (motion pictures) ; Thornhill v. Alabama, 310 U.S. 88 (1940) (picketing) ; Stromberg v. California, 283 U.S. 359 (1931) (displaying a flag).

Blevens was essentially punished for the same type of political activity which the Smith Act proscribes. See notes 13-14 supra. Section 2(a) (3) of the Smith Act makes unlawful organizing or attempting to organize, being a member of, or affiliating with, any group which advocates the violent overthrow of the government. 18 U.S.C. \& 2385, para. 3 (1952). No cases have yet arisen under the affiliation provision of this section. But cases under other clauses of $\S 2$ (a) (3) indicate that affiliation would fall under the First Amendment. For example, the Supreme Court has held that the activity proscribed by the organizing provision of the Smith Act contains an element of "speech" as that term is used in the First Amendment. Dennis v. United States, 341 U.S. 494 (1951). See also Gorfinkel \& Mack, Dennis v. United States and the Clear and Present Danger Rule, 39 CALIF. L. Rev. 475, 484-87, 488-89 (1951); Mendelson, Clear and Present Danger-From Schenck to Demis, 52 Colum. L. REv. 313, 330 (1952). Subsequent cases considering the organizing provision and the membership provision have ruled that First Amendment activity is involved. United States v. Lightfoot, 228 F.2d 861, 868-70 (7th Cir.), cert. granted, 76 Sup. Ct. 543 (1956) (membership provision); Yates v. United States, 225 F.2d 146 (9th Cir.), cert. granted, 350 U.S. 860 (1955) (organizing provision); cf. United States v. Flynn, 216 F.2d 354 (2d Cir. 1954), cert. denied, 348 U.S. 909 (1955) (advocacy). Only the Fourth Circuit has departed from this view. Scales v. United States, 227 F.2d 581 (4th Cir. 1955) (membership provision); Frankfeld v. United States, 198 F.2d 679 (4th Cir. 1952), cert. denied, 344 U.S. 922 (1953) (organizing provision). But see opinion denying a petition for rehearing. $198 \mathrm{~F} .2 \mathrm{~d}$ at 690 .

That Blevens' affiliation with a Communist group occurred in a foreign country does not mean that the constitutional protections afforded by the Bill of Rights can be denied the accused. Cf. Wade v. Hunter, 336 U.S. 684 (1949) (double jeopardy provision of Fifth Amendment applicable to court-martial of soldier accused of rape committed in Germany); United States v. Greer, 3 U.S.C.M.A. 576, 13 C.M.R. 132 (1953) (constitutional right against self-incrimination violated during court-martial for crime committed in Korea). 
sonnel from the right to a grand jury presentment. 18 And since the Sixth Amendment guarantee of trial by jury applies only when this procedural right was accorded under the common law, an accused is not entitled to a jury trial in a military court. ${ }^{10}$ But no such exceptions are contained in the First Amendment; on the contrary, judges have indicated that the broad language of the First Amendment encompasses the armed forces. ${ }^{20}$ Such a conclusion seems warranted in an era of widespread compulsory military service, ${ }^{21}$ for the right of free expression of a large segment of the community should not be subject to unlimited restrictions on the basis of a military status which may be involuntary.22

Since Blevens' conviction may have abridged protected speech, the court should have considered whether the abridgement met constitutional require-

18. "No person shall be held to answer for a capital, or otherwise infamous crime, unless on a presentment or indictment of a Grand Jury, except in cases arising in the land or naval forces ...." U.S. Const. amend. V.

19. Ex parte Quirin, 317 U.S. 1, $38-39$ (1942) ; Burns v. Lovett, 202 F.2d 335, 340 (1952), aff'd sub nom. Burns v. Wilson, 346 U.S. 137 (1953).

20. When previously presented with a First Amendment issue, the members of the Court of Military Appeals had expressly stated that First Amendment protections apply to the military. United States v. Voorhees, 4 U.S.C.M.A. 509, 531, 16 C.M.R. 83, 105 (1954) (Quinn, C.J.); id. at 535, 16 C.M.R. at 109 (Latimer, J., concurring in part and dissenting in part); $i d$. at 545, 552, 16 C.M.R. at 119, 126 (Brosman, J., dissenting). Chief Justice Quinn has declared that servicemen retain all constitutional rights except for those specifically denied them by the Constitution itself. $I d$. at 531, 16 C.M.R. at 105; United States v. Sutton, 3 U.S.C.M.A. 220, 228, 11 C.M.R. 220, 228 (1953) (dissent). See also WINTHRop, op. cit. supra note 1 , at 656 . All the above judges recognize limitations on the First Amendment rights of servicemen similar to those discussed in the text at notes 28-31 infra. But their opinions reflect the belief that the amendment is applicable to the armed forces.

The Supreme Court has clearly indicated that servicemen do not sacrifice their constitutional rights by virtue of their military status. Burns v. Wilson, 346 U.S. 137, 142 (1953). The Court of Military Appeals has expressed the same view. United States v. Voorhees, stcpra; United States v. Deain, 5 U.S.C.M.A. 44, 50, 17 C.M.R. 44, 50 (1954); United States v. Sutton, supra at 228 (dissenting opinion). But see United States v. Deain, supra at 56, 17 C.M.R. at 56 (concurring opinion). And specific constitutional guarantees have been held to apply to the military. E.g., Wade v. Hunter, 336 U.S. 684 (1949) (right against double jeopardy) ; Powers v. Hunter, 178 F.2d 141 (10th Cir. 1949) (right against cruel and unusual punishment) ; United States v. Greer, 3 U.S.C.M.A. 576, 13 C.M.R. 132 (1953) (right against self-incrimination). See also Comment, Military Justice and the Constitution-Improventents Offered by the New Uniform Code of Military Justice, 29 Texas L. Rev. 651 (1951.) ; Comment, Constitutional Rights of Persons before a Court Martial, 3 DE PaUL L. Rev. 95 (1953).

21. All male citizens of the United States between the ages of $18 \mathrm{I} / 2$ and 26 years are liable for service in the armed forces of the United States unless they qualify under exceptions to the present Selective Service Act, 62 STAT. 604 (1948), as amended, 50 U.S.C. app. $\$ 454$ (1952).

22. Cf. the reasoning of the Attorney General holding the Hatch Act, which requires dismissal of federal employees actively engaged in political activities, inapplicable to servicemen during effective periods of Selective Service Acts: ". . . Congress could have contemplated only officers and employees ... who could exercise a choice between a politi- 
ments. The rights guaranteed by the First Amendment are not absolute freedoms, ${ }^{23}$ and a balancing of conflicting interests may show the need for some restriction. ${ }^{24}$ Though individuals should be free to express themselves on controversial subjects in order that the truth may emerge, ${ }^{25}$ other substantial interests of society may clash with the exercise of free speech. In the resolution of this conflict speech may be constitutionally restricted only if two conditions are fulfilled: (1) the conflicting interest of society is so substantial that its impairment is a substantive evil which Congress has a right to prevent, ${ }^{26}$ and (2) the particular exercise of speech creates a clear and present danger of this substantive evil. 27

When applied to the military these prerequisites take on a particular stamp, for freedom of expression in the armed forces is subject to limitations not present in a civilian setting. The purpose of the military establishment is to

cal career and Government office or employment. No such choice exists for an officer or enlisted man ordered to active duty without his consent.'" 40 OPS. ATT'Y GEN. 103 (1941).

For discussion of both the social interest and military benefit in maintaining freedom of speech in the military, see Chafee, Free SpeEch in tre United States 461-62 (1941).

23. See, e.g., Dennis v. United States, 341 U.S. 494, 503, 508 (1951); id. at 524-25 (Frankfurter, J., concurring); id. at 581 (Douglas, J., dissenting on other grounds); Chaplinsky v. New Hampshire, 315 U.S. 568, 571 (1942). And see, generally, ChafEE, op. cit. supra note 22; Emrerson \& Haber, Political and Civil Rights in the United States cc. IV-VIII (1952).

24. See, e.g., Martin v. City of Struthers, 319 U.S. 141, 143 (1943) ; Schenck v. United States, 249 U.S. 47 (1919) ; Dennis v. United States, supra note 23, at 524-25 (concurring opinion); ChAFEE, op. cit. supra note 22 , at 31,35 .

25. See, e.g., Dennis v. United States, 341 U.S. 494, 503 (1951) ; American Communications Ass'n v. Douds, 339 U.S. 382, 394-95 (1950) ; Terminiello v. Chicago, 337 U.S. 1, 4 (1949); Thornhill v. Alabama, 310 U.S. 88, 95 (1940); De Jonge v. Oregon, 299 U.S. 353, 365 (1937) ; CHAFEE, op. cit. supra note 22, at 31-35.

26. The Supreme Court has found the following to be substantial interests which may be protected even though their protection abridges the right to speak: protection of the government from overthrow by violence, Dennis v. United States, supra note 25; public safety, morality or health, Thomas v. Collins, 323 U.S. 516, 536 (1945); regulated use of the public highways to assure safety and convenience, Cox v. New Hampshire, 312 U.S. 569,574 (1941) ; reasonable quiet protected from loud and raucous noises from sound amplifier trucks, Kovacs v. Cooper, 336 U.S. 77 (1949); welfare of children, Prince v. Massachusetts, 321 U.S. 158 (1944).

On the other hand, some interests have been held too inconsequential to warrant restriction of speech. E.g., property rights of a corporation owning an entire town, Marsh v. Alabama, 326 U.S. 501, 509 (1946); registration for identification purposes, Thomas v. Collins, 323 U.S. 516, 526, 540 (1945) ; prevention of crime and protection of householder from annoyance and intrusion, Martin v. City of Struthers, 319 U.S. 141, 145 (1943) ; preventing mere animosity in listeners, Cantwell v. Connecticut, 310 U.S. 296, 311 (1940).

27. Dennis v. United States, 341 U.S. 494 (1951), is the leading recent Supreme Court discussion of the meaning and application of the clear and present danger test. Cases expounding the doctrine are collected in the appendix to the opinion of Justice Frankfurter. Id. at 556-61 (concurring opinion). For discussions of what the clear and present danger test means in view of the Dennis decision, see, e.g., Antieau, Dennis v. United StatesPrecedent, Principle or Perversion?, 5 Vand. L. Rev. 141 (1952) ; Gorfinkel \& Mack, supra note 17; Mendelson, supra note 17. 
serve as an effective fighting force capable of preserving national security. ${ }^{28}$ This purpose is a substantial interest which narrows the scope of permissible First Amendment activities. Accordingly, penal sanctions ${ }^{29}$ may be imposed on a serviceman for an exercise of speech which obstructs the purpose of the military. Good order and discipline are essential to military effectiveness. ${ }^{30}$ Thus, any impairment of these requirements by an exercise of speech creates, as a matter of law, a clear and present danger to the substantial interest of national security. ${ }^{31}$

In contrast, discrediting the armed forces by engaging in forms of unorthodox political expression during off-duty hours should not be punishable per

28. See, e.g., United States v. Voorhees, 4 U.S.C.M.A. 509, 531, 16 C.M.R. 83, 105 (1954); Hearings Before a Subcommittee of the House Committee on Armed Services on H.R. 249S, 81st Cong., 1st Sess. 779, 816 (1949) ; Hearings Before a Subcommittee of the Senate Committee on Armed Services on S. 857 and H.R. 4080, 81st Cong., 1st Sess. 176, 224 (1949) (hereinafter cited as Senate Hearings).

29. Connection with organizations advocating violent overthrow of the government may warrant dismissal from the armed forces. Dep'T of Defense Directive No. 5210.9, If VII (April 7, 1954) (Military Personnel Security Program Directive); Special Regulations 600-220-1, If 10,11,30c(7), 33c (June 18, 1954) (Military Personnel Security Program, Army Regulations); Hatch Act, 53 Stat. 1148 (1939), as amended, 5 U.S.C. $\$ 118 j$ (1952). Similarly, dismissal may follow from taking an active part in political campaigns. Hatch Act, supra at $\$ 118$ i. But see 40 Ops. Atr'y GeN. 103, 105-06 (1941), discussed at note 22 supra.

If Blevens had merely been discharged from the army for affiliating with the SSD, such a non-penal sanction would not have violated the First Amendment. Adler v. Board of Education, 342 U.S. 485 (1952) ; Garner v. Board of Public Works, 341 U.S. 716 (1951); United Public Workers v. Mitchell, 330 U.S. 75 (1947). Yet, when penal sanctions, rather than mere dismissal from government service, are employed to enforce prohibitions of "speech" activity, the demands of the First Amendment must be met. E.g., Dennis v. United States, 341 U.S. 494 (1951) ; Stromberg v. California, 283 U.S. 359 (1931). This distinction between penal and non-penal sanctions has been considered "crucial." American Communications Ass'n v. Douds, 339 U.S. 382, 408 (1950).

30. E.g., Comments from Members of Judge Advocates Association on Questionnaires on the Uniform Code of Military Justice, Senate Hearings 227; see also Statement on Behalf of the American Legion, id. at 176.

31. Speech interfering with loyalty and discipline has been considered such a serious threat to military success that it may be the basis in itself for applying penal sanctions. E.g., Pierce v. United States, 252 U.S. 239 (1920); id. at 272 (Brandeis and Holmes, JJ., dissenting on other grounds); Schenck v. United States, 249 U.S. 47 (1919) ; Dunne v. United States, 138 F.2d 137, 140-41, 145 (8th Cir.), cert. denied, 320 U.S. 790 (1943); United States v. McQuaid, 5 C.M.R. 525 (1952) ; cf. Dennis v. United States, 341 U.S. 494, 504 (1951) ; Sanford v. Callan, 148 F.2d 376 (5th Cir.), cert. denied, 326 U.S. 679 (1945).

Specific articles of the Uniform Code proscribe "speech" activity in order to maintain discipline. E.g., art. 89 (disrespect towards superior officer); art. 91(3) (insubordinate conduct towards noncommissioned officer by language or deportment); art. 117 (provoking speeches or gestures). See also art. $\$ 8$, which prohibits contempt toward high governmental oficials. Members of the Senate subcommittee expressed concern over the restrictions which this article placed on freedom of expression. Senate Hearings at 330-33; cf. id. at 209. There are no reported cases under the Uniform Code employing art. 88 and its 
se. ${ }^{32}$ The international and domestic reputation of the military is important, but less essential to military success than good order and discipline. ${ }^{33}$ In light of its indirect relation to the purpose of the military, injury to reputation, standing alone, should not be considered a substantive evil warranting restriction of First Amendment rights. ${ }^{34}$ If discreditability were considered such a substantive evil, a serviceman's political expressions could be punished merely because of their unpopularity. For an exercise of speech by a serviceman tends to discredit the armed forces if it offends the standards of the community. ${ }^{35}$ Yet political activities cannot be restricted merely under a standard of community disapproval; that is the very basis for punishment which the First Amendment was designed to prohibit. ${ }^{36}$

Impairment of military reputation by the exercise of political activities must be distinguished, however, from impairment by conduct entailing no element

predecessor section was seldom used. Id. at 332. But see Sanford v. Callan, 148 F.2d 376 (5th Cir.), cert. denied, 326 U.S. 679 (1945) (affirming conviction under predecessor of art. 88).

Military personnel are also forbidden to engage in outside activities, including political ones, if this would interfere with the full and proper discharge of their duties. E.g., Army Regulations No. 600-10, If $12 a, 18 c$ (1) (Dec. 15, 1953).

32. When an exercise of political expression reflecting lack of sympathy with American military goals or foreign policy occurs in the course of official duty or in the presence of other military personnel, it may be punished as conduct prejudicial to good order and discipline. United States v. McQuaid, 5 C.M.R. 525, 530 (1952) (poster criticizing military effort placed on door of air force base library). Yet, when such an exercise of speech occurs away from a military post and is not directed toward military personnel, it is punishable, if at all, as conduct of a nature to discredit the armed forces. Cf. United States v. Hughes, 7 C.M.R. 803, 810 (1953) (misconduct held unrelated to military discipline and thus could only be punished as discreditable conduct).

33. Conduct injuring the reputation of the armed forces was not made punishable until 1916. Even then it was inserted only for a collateral purpose and not as a factor essential to military success. See note 4 supra.

In terms of national security, the reputation of the armed forces is important in two areas: (1) hostile countries must entertain a high regard for American military strength so that they will be deterred from initiating aggression; and (2) American civilians must have a favorable opinion of the armed forces so that they will support the efforts and have confidence in the ability of the military.

34. For other interests which have been held too insubstantial to justify suppression of First Amendment freedoms, see note 26 supra.

35. The discreditable conduct clause of art. 134 may be employed to punish activities which, though not illegal, are regarded with disfavor in the community. E.g., art. 134 may be used to punish servicemen for failure to pay just debts. Manual $\Uparrow 213 b$; United States v. Andrews, 9 C.M.R. 667, 673-74 (1953).

36. "Plainly a community may not suppress ... the dissemination of views because they are unpopular, annoying or distasteful .... That would be a complete repudiation of the philosophy of the Bill of Rights." Murdock v. Pennsylvania, 319 U.S. 105, 116 (1943). See also Brief of the Committee on the Bill of Rights of the American Bar Ass'n as Amicus Curiae, p. 8, Hague v. CIO, 307 U.S. 496 (1939) ("no principle could be more destructive of ... free speech than to judge [its] permissability by any standard of its popularity"); CHAFEE, op. cit. supra note 22 , at 481-82. 
of speech. Restriction of "conduct" is permissible if reasonably related to protection of a substantial interest. ${ }^{37}$ But "speech" is shielded from punishment by the First Amendment safeguard of freedom of expression; it may not be suppressed without a showing of clear and present danger to a substantial interest. $^{38}$ Accordingly, discreditable speech may not be punished merely because it injures military reputation, since reputation is not essential to military success. ${ }^{39}$ But discreditable conduct, not having the social value or constitutional protection afforded to speech, can be punished because reputation is reasonably related to military success.

Moreover, since discreditable conduct can be punished, the advocacy of such conduct may be subjected to penal sanctions if the speech creates a clear and present danger that the conduct will result. ${ }^{40}$ In Blevens, however, the justification for punishing an exercise of speech was not that the speech advocated and tended to incite discreditable actions by servicemen. Blevens' political activities were punished only because the reputation of the United States Army was injured as an incidental, unintended effect of his affiliation with a Communist group. ${ }^{41}$ The government presumably feared that members of the com-

37. Nebbia v. New York, 291 U.S. 502, 525, 537-39 (1934) ("reasonable relation to a proper legislative purpose") ; cf. United States v. Carolene Products Co., 304 U.S. 144, $152-54$ (1938).

38. The Supreme Court has frequently asserted that restriction of speech requires a greater likelihood of substantial injury than restriction of conduct. Board of Education v. Barnette, 319 U.S. 624, 639 (1943) ; Schneider v. Town of Irvington, 308 U.S. 147, 161 (1939) ; United States v. Carolene Products Co., 304 U.S. 144, 152 n.4 (1938). Thus, First Amendment rights are often said to occupy a "preferred pasition." E.g., Murdock v. Pennsylvania, 319 U.S. 105, 115 (1943); see also Thomas v. Collins, 323 U.S. 516, 529-30 (1945) ; Mason, The Core of Free Government, 1938-40: Mr. Jinstice Stone and "Preferred Frecdoms," 65 Y YLE L.J. 597 (1956). But, for a critical analysis and chronological account of the development of the "preferred position" doctrine, see Kovacs v. Cooper, 336 U.S. 77, 89-97 (1949) (concurring opinion).

39. See note 33 supra and accompanying text.

40. Cf. Dennis v. United States, 341 U.S. 494 (1951) (advocacy of violent overthrow of government punishable when clear and present danger of attempted overthrow). Injury to military reputation by conduct, in contrast to injury by speech, may be classified a "substantive evil," see note 26 supra and accompanying text, because conduct lacks the social value of speech and may properly be suppressed to protect the reputation of the armed forces.

41. An exercise of speech adzocating illegal action must be distinguished from an exercise of speech which may lead to illegal action, or other harmful consequences, undesired by the speaker. For example, advocacy of unlawful rioting may be constitutionally suppressed if it creates a clear and present danger of a riot ensuing. Feiner v. New York, 340 U.S. 315, 320-21 (1951) ; Cantwell v. Connecticut, 310 U.S. 296, 308 (1940) (dictum). But speech which is otherwise protected by the First Amendment may not be quashed on the ground that listeners, enraged by the speaker's remarks, will engage in violence. Terminiello v. Chicago, 337 U.S. 1, $4-5$ (1949), reversing 400 I11. 23, 79 N.E.2d 39 (1948) ; Hague v. CIO, 307 U.S. 496, 516 (1939) ; cf. CHAFEE, op. cit. supra note 22, at 422-35. Similarly, the distribution of handbills may not be suppressed on the ground that recipients litter the streets with them-a result not intended by the speaker. Schneider v. Town of Irvington, 308 U.S. 147, 162 (1939). 
munity who knew of Blevens' political associations would, as a result, entertain a less favorable opinion of the armed forces. Yet, the Supreme Court has held that the mere subjective effect on "listeners" of speech not advocating illegal action on their part is not by itself a substantive evil justifying the suppression of First Amendment activity. ${ }^{42}$

If injury to military reputation by political expressions is not a substantive evil in itself, discreditable speech can be punished only if it creates a clear and present danger of something that is a substantive evil. ${ }^{43}$ In many instances, a serviceman's expressions of belief, including association with controversial political groups, might conceivably impair the reputation of the armed forces. ${ }^{44}$ The discredit resulting from a particular exercise of speech may be so significant that it constitutes a clear and present danger to national security or military success. Whenever such danger is established, punishment of speech will be consistent with constitutional requirements. Thus, the court must consider the circumstances surrounding the exercise of speech ${ }^{45}$-the extent of the impairment of military reputation and the resulting potential repercussions. The following factors are relevant to this inquiry $:^{46}$ whether the accused was wearing his uniform at the time he engaged in discreditable forms of political expression, whether the military status of the speaker was otherwise brought home to those who observed him, whether the United States was at war, whether the exercise of speech was of such a nature that a substantial segment of the community would be aware of it, whether the political expression took

42. Martin v. City of Struthers, 319 U.S. 141, 145 (1943) (annoyance resulting from door-to-door distribution of leaflets advertising religious meetings) ; Cantwell v. Connecticut, 310 U.S. 296, 311 (1940) (animosity resulting from playing anti-Catholic record in Catholic neighborhood) ; cf. Kovacs v. Cooper, 336 U.S. 77, 81-83 (1949) (statute prohibiting sound amplifying devices emitting "loud and raucous" noises is constitutional regulation of speech, though absolute prohibition of all sound amplification would be unconstitutional); Saia v. New York, 334 U.S. 558 (1948).

43. See text at notes 26-27 supra.

44. Although the facts in Blevens are unique, a serviceman's conduct could be considered discreditable in more common situations. For example, a soldier on furlough might actively participate in a meeting advocating the recognition of Communist China or forcible resistance to the racial integration of public schools. In each case, the same constitutional prerequisites would have to be met before the conduct could be punished.

45. See Schenck v. United States, 249 U.S. 47, 52 (1919) (Holmes, J.).

46. For factors which the Supreme Court has deemed relevant in other free speech cases, see, e.g., Dennis v. United States, 341 U.S. 494, 510-11 (1951) (inter alia, a highly organized conspiracy, rigidly disciplined members subject to their leaders' call, the inflammable nature of world conditions); $i d$. at $587-89$ (dissenting opinion of Douglas, J.) (the nature of Communism as a force on the world scene; the strength, numbers and tactical positions in strategic jobs of defendants and their followers; whether the Communists are known to the FBI and can be quickly rounded up in case of war); Frohwerk v. United States, 249 U.S. 204, 208-09 (1919) (whether defendant who circulated newspaper designed to obstruct recruiting made special effort to reach men who were subject to the draft; whether the circulation of the paper was in areas where defendant knew "a little breath would be enough to kindle a flame"); Schenck v. United States, 249 U.S. 47, 52 (1919) (whether the nation was at war). 
place in an area where the prestige of the United States military was of particular importance to national security. ${ }^{47}$

Accordingly, the Court of Military Appeals should have determined whether the discredit to the army resulting from Blevens' affiliation with the SSD was, in light of the surrounding circumstances, a clear and present danger to national security. East Germany is a crucial area in the Cold War, and members of an official agency of that government knew that Blevens was a United States soldier. On the other hand, the United States was not at war, Blevens did not wear his uniform while in East Germany, and only a scant segment of the East German populace was aware of his activities. ${ }^{48}$ In addition, domestic public opinion of the military was presumably unaffected by Blevens' conduct, since the government did not show that news of his activities was circulated in this country. On balance, it would seem that the injury to the reputation of the services caused by Blevens' association with a Communist organization did not create a clear and present danger to national security or military success. Undoubtedly, Blevens' conduct deserved punishment. ${ }^{49}$ But the conviction, based as it is on an exercise of speech without any consideration of the constitutional issue, establishes an unfortunate precedent for military courts.

47. Military courts have recognized that factors analogous to the foregoing may be relevant in determining whether misconduct is of a nature to discredit the armed forces. Compare United States v. McGlone, 18 C.M.R. 525, 532 (1954) (misconduct held discreditable when observed by military personnel and civilian employees), with United States v. Walters, 11 C.M.R. 355, 362-63 (1953) (same misconduct held not discreditable in absence of other circumstances). But see United States v. MoMurtry, 1 C.M.R. 715, 719 (1951) (drunkenness in public place discreditable, though accused was in civilian clothes; conviction not dependent on whether onlookers know at the time that accused is in the service). Even if an unpopular exercise of political expression may be held discreditable because observed by others, the extent of the publicity and the seriousness of the discredit must still be investigated to determine whether the speech may be constitutionally punishe'd.

48. Blevens was given civilian clothing by SSD agents. He was also given an identification pass and instructed to say that he was a Russian if anyone asked. United States v. Blevens, 5 U.S.C.M.A. 480, 488, 18 C.M.R. 104, 112 (1955).

49. Activities in connection with overthrow of the government by force and violence may properly be prohibited. Dennis v. United States, 341 U.S. 494 (1951). Such activities are especially condemnable when carried on by military personnel. Most likely a conviction under the Smith Act could have been obtained if the prosecution had been properly conducted. See also 18 U.S.C. \$ 953 (1952) (prohibiting private dealings with foreign government by American citizen with intent to influence policy of that country toward United States). 